\title{
Analysis of Growth and Elasticity of Regional Native Income to Brutto Regional Domestic Product
}

\author{
Siti Fatimah; Yusuf Hasbullah; Abdul Manan; Muhammad Alwi; Akung Daeng \\ Faculty of Economics and Business Department of Economics and Development Studies, University of Mataram, \\ Indonesia
}

http://dx.doi.org/10.18415/ijmmu.v8i5.2516

\begin{abstract}
Research Objectives to find out the growth of Regional Native Income (In Indonesia Called PAD) and the form and magnitude of Elasticity of Regional Native Income about the growth rate of Product Domestic Regional Brutto (PDRB) East Lombok Regency and since 2016-2019. This type of research includes descriptive research. This research was conducted in East Lombok Regency of West Nusa Tenggara Province. The data collected in the study include data on the Regional Budget (In Indonesia called APBD) for the last 4 (four) years which include: Regional Revenue, Regional Original Budget, Legal Hain Budget from 2016 to 2019. The results showed that the rate of development of Regional Native Income to Brutto Regional Domestic Product based on Prevailing Prices (In Indonesia called ADHB) East Lombok District in 2016-2019 with an average growth rate for 4 (four) years starting from 2016-2019 reached 10.29 percent. The rate of development of Regional Native Income to Brutto Regional Domestic Product based on Constant Prices in 2010 in East Lombok District in 2016-2019 with an average growth rate for 4 (four) years starting from 2016-2019 reached 11.36 percent. The contribution of the balanced fund to the regional income of East Lombok Regency is so influential that the impact on the rate of economic growth reflected in the growth of Brutto Domestic Regional Product based on Prevailing Prices (In Indonesia such as PDRB ADHB) and Brutto Domestic Regional Product based on Constant Price (In Indonesia called PDRB ADHK) East Lombok Regency for 4 (four) Years (2016-2019) is relatively significant. Pad elasticity to Product Domestic Regional Brutto both based on Prevailing Prices and based on Constant Prices in 2010 on average for the last 4 (four) years shows a trend that is positive or Elastic. This means that if PAD increases by one unit (\%), then PDRB will increase by more than one unit $(\%)$.
\end{abstract}

Keywords: Growth; Elasticity; Local Revenues; Product Domestic Regional Brutto

\section{Introduction}

One of the indicators to see the economic development of a region through the concept of Product Domestic Regional Brutto (PDRB) (Oktaviana \& Amalia, 2018). Conceptually PDRB is the result of adding value brutto in the form of goods and services produced by all production units within the 
boundaries of a particular region or region for one year (Dama et al., 2016). Viewed from the point of view of the classification of PDRB can be seen based on the prevailing price that describes the added value of goods and services calculated using the price on each year, while the PDRB based on constant price shows the added value of goods and services calculated by using the price in a given year as the base year of its calculation.

In terms of the benefits of PDRB based on prevailing prices can be used to see the shift in economic structure, while in terms constant prices can be used to know economic growth from year to year. Thus PDRB is an indicator to know the extent of the success of the government in utilizing existing resources that can be used as planning and decision-making materials (Juniarsih et al., 2021).

If observed in time series since 2016-2019 PDRB growth in East Lombok regency shows fluctuating growth rate. This condition illustrates to us that these growth fluctuations inform us of the growth dynamics of each economic sector each year. This dynamic is at the same time a real condition of economic sector growth as well as structural shifts between economic sectors. Conceptually, when viewed from nine sectors of the existing economy can be classified into three main sectors covering the primary sector, the secondary sector, and the tertiary sector. It appears that over the last five years both growth and structural shifts have shown quite encouraging dynamism. But the dynamics of growth above whether indicate a shift in economic structure or not, so it is necessary to analyze and study more indepth.

Judging from the angle of elasticity, of course, it will also change every year in line with the growth rate of PDRB (Arifin, 2020). But the change is meant to influence the growth rate of PDRBforming variables. This also requires a more comprehensive study as a foundation based on planners in allocating APBD funds that are expected to be more oriented to public sector services. Whereas if observed conceptually that the elasticity of PDRB growth describes the degree of sensitivity or response of changes in PDRB to factors that affect it such as growth between economic sectors. Fluctuations in economic sector growth will have a simultaneous impact on the small elasticity of PDRB. The greater the ups and downs of elasticity at the same time will indicate the level of elasticity of PDRB growth, whether elastic, unitary, or inelastic.

Research Objectives to find out (a) Regional Native Income Growth (PAD) in relation to the growth rate of Product Domestic Regional Brutto (PDRB) East Lombok Regency and since 2016-2019; (b) The form and magnitude of The Elasticity of Pad Regional Native Income in relation to the growth rate of Product Domestic Regional Brutto PDRB East Lombok Regency since 2016-2019.

\section{Research Methods}

This type of research includes descriptive research which is research conducted to find out the value of independent variables, either one or more variables (independent) without making comparisons or connecting with other variables. This research was conducted in East Lombok Regency of West Nusa Tenggara Province.

The data collected in the study include APBD data for the last 4 (four) years which include: Regional Revenue, Regional Original Income, Shah Hain Pendpatan during the period of 2016-2019 by: (1) Library Research, namely by studying books, scientific papers, scientific journals and other documents related to PDRB growth analysis and elasticity in accordance with the title of the study; (2) Field Research, namely conducting direct observations in the field, especially at the Financial Bureau of the Regional Secretariat of East Lombok Regency of West Nusa Tenggara Province in connection with the data and information related to the above research variables. 
This study uses primary data consisting of APBD data, APBD changes, APBD calculation report, the realization of regional revenues, realization of regional expenditures, Memorandum of Calculation of APBD, Cash Flow and Calculation Book of East Lombok District Budget of West Nusa Tenggara Province in the Fiscal Year 2016-2019. While other secondary data in the form of published data consisting of PDRB data, demographic data, APBD development, regional revenue and expenditure, and budgeting mechanisms, and other East Lombok district data support the title of research.

PAD's growth in PDRB over the last five years (2006-2010) will be analyzed with Widodo's formulation in Muin (2003):

$$
\Delta \mathrm{Xt}=\frac{\mathrm{Xit}-\mathrm{Xit}-1}{\mathrm{Xit}-1} \times 100 \%
$$

$$
\begin{array}{ll}
\text { dimana: } & \\
\Delta \mathrm{Xt} & =\text { PAD growth rate to PDRB } \\
\Delta \mathrm{X} 1 \mathrm{t} & =\text { PAD growth rate } \\
\Delta \mathrm{X} 2 \mathrm{t} & =\text { Growth rate of PDRB } \\
\mathrm{t} & =\text { Year txx } \\
\mathrm{t}-1 & =\text { Previous Year } \\
\mathrm{X} 1 & =\text { PAD Variable } \\
\mathrm{X} 2 & =\text { PDRB Variable }
\end{array}
$$

To find out the contribution of PAD to PDRB East Lombok regency will be analyzed using the formula:

$$
\mathrm{X}=\frac{\mathrm{A}}{\mathrm{B}} \boldsymbol{x} 100 \%
$$

where:

$\mathrm{X}=$ Percentage contribution of PAD to PDRB East Lombok Regency.

$\mathrm{A}=$ PAD Acceptance of East Lombok Regency for the nth year period.

$\mathrm{B}=$ PDRB East Lombok Regency year-to-year period.

Criteria to determine the small contribution of Regional Native Income (PAD) to Domestic Products Regional Brutto (PDRB) East Lombok District used the following criteria (Soekartawi, 1995)

Table 1: Criteria for PAD Contribution to PDRB

\begin{tabular}{lcl}
\hline No. & Besarnya Kontribusi (\%) & Criteria \\
\hline 1 & $76-100$ & Very large \\
2 & $51-75$ & Large \\
3 & $26-50$ & Quite large \\
4 & $0-25$ & Less large \\
\hline
\end{tabular}

The elasticity approach in question is:

$$
\mathrm{E}=\frac{\Delta \mathrm{PAD}}{\triangle \mathrm{PDRD}} \times 100 \%
$$

Where:

$$
\begin{array}{ll}
\mathrm{E} & =\text { Elasticity } \\
\triangle \mathrm{PAD} & =\text { PAD Changes } \\
\Delta \text { PDRB } & =\text { PDRB Changes }
\end{array}
$$




\section{Research Results}

\section{Development of Regional Native Income}

The next explanation will be presented how the growth and development of native income in East Lombok Regency over the last 5 (five) years will be presented in table 2:

\begin{tabular}{cccc}
\multicolumn{5}{c}{ Table 2. Regional Native Income (PAD) East Lombok Regency Year 2016-2019 (millions of } \\
rupiah)
\end{tabular}

Based on the data table above can be explained that the growth rate of regional native income seen in terms of budget realization since 2016 growth of 10.23 percent, in 2017 rose to 11.76 percent, in 2018 remained at 11.76 percent and in 2019 decreased to 10.97 percent. The highest growth rate occurred in 2017 and 2018 at 11.76 percent. The average growth rate for 5 (five) years starting from 2016-2019 reached 11.18 percent.

\section{Development of Balance Fund Contribution to PDRB (ADHB)}

PDRB on the basis of prevailing prices describes the added value of goods and services calculated using the price at the time period. So the PDRB is intended to describe how the economic growth of East Lombok Regency during the observation period is based on the real price of goods and services in the observation year. Furthermore, to see how the role and contribution of Balanced Fund to PDRB on the Basis of Prevailing Prices (ADHB) in East Lombok Regency for 4 (four) years from 20166-2019 will be presented in table 3:

Table 3. Contribution of Balanced Fund to The Rate of Economic Growth (PDRB) on the Basis of Prevailing Prices of East Lombok Regency in 2016-2019 (millions of rupiah).

\begin{tabular}{llcl}
\hline Year & Balance Fund & $\begin{array}{c}\text { PDRB On The Basis of } \\
\text { Applicable Prices }\end{array}$ & Contribution Percentage (\%) \\
\hline 2016 & $1.286 .363 .213,7$ & $15.971 .050,90$ & 9,76 \\
2017 & $1.513 .368 .486,7$ & $17.549 .454,41$ & 10,98 \\
2018 & 1.782 .786 .455 & $18.828 .465,97$ & 10,73 \\
2019 & 1.801 .638 .631 & $20.305 .603,50$ & 10,78 \\
Amount & $6,384.156 .786,40$ & $72.654 .574,70$ & 42,25 \\
Average & $1.596 .039 .196,60$ & $18.163 .643,67$ & 10,56 \\
\hline
\end{tabular}

Based on the data table above can be explained that the growth figures of The Balance Fund Contribution to the Rate of Economic Growth (PDRB) on the Basis of Prevailing Prices East Lombok District in 2016-2019 as follows: starting from 2016 the contribution growth is 9.76 percent, in 2017 increased to 10.98 percent, in 2018 it decreased to 10.73 percent, and in 2019 to 10.78 percent. The highest growth rate occurred in 2017 which was 10.98 percent. The average growth rate for 4 (four) years starting from 2016-2019 reached 10.56 percent. 


\section{Development of Balance Fund Contribution to PDRB (ADHK)}

PDRB on the basis of constant price describes the added value of goods and services calculated using the price applicable to a particular period (the year 2010). So the PDRB is intended to describe how the economic growth of East Lombok Regency during period observations based on the price of the year that has been determined as the year of calculation (the year 2010). Next to see how the growth of Balance Fund Contribution to PDRB on the Basis of Constant Price in 2010 (ADHK) East Lombok for 4 (four) years from 2016-2019 will be presented in table 4.

Table 4. Contribution of Balanced Fund to The Rate of Economic Growth (PDRB) on the Basis of Constant Prices in 2010 East Lombok District year 2012-2016 (millions of rupiah).

\begin{tabular}{|c|c|c|c|}
\hline Year & Balance Fund & PDRB on Constant Price Basis 10 & Contribution Percentage (\%) \\
\hline 2016 & $1.129 .526,0$ & 10.721 .723 & 10,53 \\
\hline 2017 & $1.243 .781,0$ & 11.249 .937 & 11,06 \\
\hline 2018 & $1.335 .017,0$ & 11.913 .551 & 11,21 \\
\hline 2019 & $1.749 .586,0$ & 12.535 .284 & 13,95 \\
\hline Jumlah & $5.457 .910,0$ & 46.420 .495 & 46,75 \\
\hline Rata-rata & $1.364 .477,0$ & 11.605 .123 & 11,68 \\
\hline
\end{tabular}

Based on the data table above can be explained that the growth figures of The Balance Fund Contribution to The Rate of Economic Growth (PDRB) On the Basis of Constant Prices East Lombok District in 2016-2019 as follows: starting from 2016 the contribution growth is 10.53 percent, in 2017 increased to 11.06 percent, in 2018 increased to 11.21 percent, in 2019 increased again to 13.95 percent. The highest growth rate occurred in 2019 which was 13.95 percent. The average growth rate for 4 (four) years starting from 2016-2019 reached 11.68 percent.

\section{Brutto Regional Domestic Product (PDRB) Development}

Brutto Regional Domestic Revenue (PDRB) is all the added value created from various economic activities in a region in a certain period (one year). The basic calculation of PDRB / PDRB since 2016 using the base year 2010 on the basis of SNA 2008. One of the implications of the use of SNA 2008 is a nominal change and a change in the classification of PDRB from 9 sectors to 17 categories. PDRB on the basis of prevailing prices (ADH) East Lombok District in 2016 reached 16.04 Trillion rupiahs.

If we want to see the economic structure of an area can be seen from the contribution of each category to the formation of PDRB. East Lombok PDRB figures show that the category of agriculture, forestry, and fisheries has the largest contribution in the formation of PDRB. As an illustration in 2016 more than 1/4 (one-fourth) or 28.35 percent of east Lombok PDRB comes from the agricultural category. Although from year to year this percentage is getting smaller with relatively 'small/smooth' movements. In general, it shows slowly but surely the decline of agricultural sector business is decreasing/decreasing. In addition, PDRB based on constant prices is usually used to see economic growth in an area. In terms of the economic growth rate of East Lombok Regency in 2016 reached 5.18 percent.

Next to see how the realization and growth of PDRB (ADHK) and (ADHB) East Lombok for 4 (four) years from 2016-2019 will be presented in table 5. 
Table 5. Economic Growth (PDRB) of East Lombok Regency in 2016-2019 (millions of rupiah)

\begin{tabular}{lrrrr}
\hline No. & Year & $\begin{array}{l}\text { PDRB on The Basis } \\
\text { of Applicable Prices }\end{array}$ & $\begin{array}{l}\text { PDRB on the Basis of } \\
\text { Constant Price 2010 }\end{array}$ & Growth (\%) \\
\hline 1 & 2016 & $15.971 .050,90$ & $12.540 .497,50$ & 9,75 \\
2 & 2017 & $17.549 .454,41$ & $13.323 .964,53$ & 10,62 \\
3 & 2018 & $18.828 .465,97$ & $13.771 .632,88$ & 10,33 \\
4 & 2019 & $20.305 .603,50$ & $14.415 .564,75$ & 10,47 \\
\multicolumn{2}{l}{$\begin{array}{l}\text { Jumlah } \\
\text { Rata-rata }\end{array}$} & $72.654 .574,70$ & $54.051,659,50$ & 41,17 \\
\multicolumn{2}{l}{} \\
\hline
\end{tabular}

Based on the data table above can be explained that the economic growth figures (PDRB) seen in terms of PDRB on the basis of prevailing prices and PDRB on the basis of constant prices 2010 starting from 2016 growth of 9.75 percent, in 2017 increased to 10.62 percent, in 2018 it decreased to 10.33 percent, and in 2019 it increased to 10.47 percent. The highest growth rate occurred in 2017 which was 10.62 percent. The average growth rate for 4 (four) years starting from 2016-2019 reached 10.29 percent.

Furthermore, if we want to see the distribution of Product Domestic Regional Brutto (PDRB) on the Basis of Applicable Prices intended for what types of field expenditures are most prominent, then the information will be presented in table 6 .

Table 6. Product Domestic Regional Brutto (PDRB) On The Basis of Prevailing Prices According to East Lombok District Expenditure year 2016-2019 (in millions of rupiah)

\begin{tabular}{llllll}
\hline No. & \multicolumn{1}{c}{ Types of Expenses } & \multicolumn{1}{c}{2016} & \multicolumn{1}{c}{2017} & \multicolumn{1}{c}{2018} & \multicolumn{1}{c}{2019} \\
\hline 1. & Household Consumption & $12.640 .425,6$ & $13.479 .947,23$ & $14.314 .969,55$ & $15.183 .158,80$ \\
2. & LNPRT Consumption & $457.517,5$ & $513.390,62$ & $594.437,20$ & $636.888,00$ \\
3. & Government Consumption & $2.713 .081,4$ & $2.915 .289,95$ & $3.004 .191,12$ & $3.074 .102,75$ \\
4. & Establishment of Fixed Capital & $5.982 .916,0$ & $6.466 .285,90$ & $6.883 .381,70$ & $7.584 .439,60$ \\
5. & Inventory Changes & $68.880,8$ & $78.226,56$ & $77.382,52$ & $76.986,49$ \\
6. & Net Expor of Goods \&Services & $-5.891 .770,5$ & $-5.903 .685,85$ & $-6.045 .896,11$ & $-6.249 .972,14$ \\
& $\quad$ P D R B & $15.971 .050,9$ & $17.549 .454,41$ & $18.828 .465,97$ & $20.305 .603,50$ \\
\hline
\end{tabular}

Based on the data table above can be explained that of the nine types of expenditures that exist, it turns out that the allocation of Product Domestic Regional Brutto (PDRB) based on the largest applicable price is intended for the type of household consumption expenditure, The Establishment of Fixed Capital, Government Consumption, even Net Export Goods \&Services continues to run a deficit for the last four years until 2019.

If we want to see the distribution of Product Domestic Regional Brutto (PDRB) on the Basis of Constant Price in 2010 intended for what types of field expenditures are most prominent, then the information will be presented in table 7 . 
Table 7. Product Domestic Regional Brutto (PDRB) On The Basis of Constant Price in 2010 By Type of Expenditure of East Lombok Regency in 2016-2019 (in millions of rupiah)

\begin{tabular}{|c|c|c|c|c|c|}
\hline No. & Types of Expenses & 2016 & 2017 & 2018 & 2019 \\
\hline 1. & Household Consumption & $9.859 .768,0$ & $10.117 .198,54$ & $10.369 .877,39$ & $10.694 .908,08$ \\
\hline 2. & LNPRT Consumption & $346.127,7$ & $372.784,00$ & 416.704,68 & $434.909,15$ \\
\hline 3. & Government Consumption & $1.854 .053,5$ & $1.932 .825,42$ & $1.959 .206,27$ & $1.987 .494,60$ \\
\hline 4. & $\begin{array}{l}\text { Establishment of Fixed } \\
\text { Capital }\end{array}$ & $4.331 .167,3$ & 4.547.225,31 & 4.707.642,69 & $5.047 .038,53$ \\
\hline 5. & Inventory Changes & $8.342,7$ & $9.342,68$ & $8.999,04$ & $8.716,15$ \\
\hline \multirow[t]{2}{*}{6.} & $\begin{array}{l}\text { Net Expor of Goods } \\
\text { \&Services }\end{array}$ & $-3.858 .961,7$ & $-3.655 .411,41$ & $-3.690 .797,18$ & $-3.757 .501,76$ \\
\hline & PDRB & $12.540 .497,5$ & $13.323 .964,53$ & $13.771 .632,88$ & $14.415 .564,75$ \\
\hline
\end{tabular}

Based on the data table above can be explained that of the nine types of expenditures that exist, it turns out that the allocation of Product Domestic Regional Brutto (PDRB) based on the constant price in 2010 is still intended for the type of new household consumption expenditures followed by the Establishment of Fixed Capital, Government Consumption, even Net Export Goods \&Services still continues to run a deficit for the last four years until 2019. Nevertheless, it turns out that the development of Product Domestic Regional Brutto (PDRB) both reviewed from the prevailing price and the constant price of 2010 continues to experience a fairly significant increase.

\section{Distribution of PDRB Growth Rate by Economic Sector}

If we want to see the PDRB growth rate according to the category or economic sector, then we will be able to observe from various categories or economic sectors as presented in table 8 .

Table 8. Brutto Domestic Regional Product Growth Rate (PDRB) By Category East Lombok District Year 2016-2019 (in percent)

\begin{tabular}{|c|c|c|c|c|c|}
\hline No. & Types of Categories & 2016 & 2017 & 2018 & 2019 \\
\hline 1. & Agriculture, Forestry and Fisheries & 2,40 & 6,04 & 1,89 & 1,30 \\
\hline 2. & Mining and Quarrying & 9,28 & 7,17 & 5,87 & 10,52 \\
\hline 3. & Processing Industry & 2,07 & 3,81 & 0,79 & 2,76 \\
\hline 4. & Electricity and Gas Procurement & 9,84 & 4,51 & 1,01 & 9,28 \\
\hline 5. & Water Supply,Waste Management\&daur Recycling & 4,96 & 4,09 & $-4,65$ & 4,77 \\
\hline 6. & Construction & 9,13 & 6,81 & 1,81 & 8,15 \\
\hline & Large Trade \&amp; Retail and Cooperatives & 7,23 & 8,12 & 5,88 & 6,48 \\
\hline & Transportation \&amp; Trade & 3,40 & 4,54 & 2,91 & 6,49 \\
\hline 9. & Provision of accommodation \&Amp; Drinking & 7,40 & 6,56 & 5,71 & 5,48 \\
\hline 10. & Information \& Communication & 8,81 & 8,43 & 5,38 & 4,10 \\
\hline 11. & Financial Services and Insurance & 13,49 & 10,50 & 5,81 & 1,21 \\
\hline 12. & Real estate & 6,63 & 6,92 & 4,97 & 4,58 \\
\hline 13. & Corporate Services & 7,22 & 5,57 & 4,91 & 4,75 \\
\hline & $\begin{array}{l}\text { Government Administration, Defense and social } \\
\text { security }\end{array}$ & 2,40 & 2,46 & 0,83 & 3,13 \\
\hline 15. & Education Services & 4,96 & 5,91 & 5,72 & 5,91 \\
\hline 16. & Health Services and Social Activities & 5,88 & 6,14 & 7,94 & 6,17 \\
\hline \multirow[t]{2}{*}{17.} & Other Services & 6,47 & 6,67 & 4,84 & 5,16 \\
\hline & Economic Growth & 5,23 & 6,25 & 3,36 & 4,68 \\
\hline
\end{tabular}


Based on the data table above can be explained that of the seventeen types of categories or economic sectors that exist, it turns out that the economic growth rate (PDRB) of East Lombok Regency is contributed by the mining sector by $10.52 \%$ followed by the electricity and gas procurement sector by $9.28 \%$, construction by $8.15 \%$ and the lowest contributed by financial and insurance services by $1.21 \%$ and the Agriculture, Forestry, and Fisheries sector by $1.30 \%$. What is interesting in the data above is the increasing role of the Agriculture, Forestry, and Fisheries sector in contributing to the rate of economic growth in East Lombok Regency. This indication shows further if we look at the economic growth rate of East Lombok Regency since 2016-2019 it fluctuates by 5.23\%, 6.25\%, 3.36\%, and 4.68\%.

\section{PAD Elasticity Against PDRB}

In economics, elasticity is a comparison of the professional change of a variable with the change of other variables or in other words elasticity measures how much sensitivity or reaction of consumers to price changes. Symbolically theoretical elasticity can be classified into E > 1 (elastic)., E < 1 (Inelastic), and $\mathrm{E}=1$ (elastic unitary). Furthermore, to see the level of sensitivity referred to can be approached in 2 (two) ways, namely based on the basis of the prevailing price and on the basis of the price of Constans. To see the sensitivity of Regional Native Income to Brutto Domestic Regional Product, it will first be seen the change of each variable referred to through the presentation of table 9.

Table 9. Rate of Change of Regional Native Income (PAD) to Brutto Domestic Regional Product (PDRB) On The Basis of Prevailing Price (ADHB) of East Lombok Regency in 2016-2019 (in millions)

\begin{tabular}{ccllcl}
\hline No. & Year & PAD & PDRB $($ ADHB $)$ & $\Delta$ PAD & $\Delta$ PDRB \\
\hline 1. & 2016 & $194.391 .179,0$ & $15.971 .050,90$ & $29.158 .676,3$ & $1.341 .642,9$ \\
2. & 2017 & $228.695 .504,7$ & $17.549 .454,41$ & $34.304 .325,7$ & $1.578 .403,5$ \\
3. & 2018 & $269.053 .535,0$ & $18.828 .465,97$ & $40.358 .030,3$ & $1.279 .011,5$ \\
4. & 2019 & $295.164 .950,0$ & $20.305 .603,50$ & $26.111 .415,0$ & $1.477 .137,6$ \\
& Amount & $987.305 .168,7$ & $72.654 .574,70$ & $129.932 .447,3$ & $5.676 .177,5$ \\
& Average & $246.826 .292,2$ & $18.163 .643,67$ & $32.483 .111,8$ & $1.419 .044,4$ \\
\hline
\end{tabular}

Based on the table data above can be explained that the Rate of Change of Regional Native Income (PAD) to Brutto Domestic Regional Product (PDRB) On the Basis of Prevailing Prices (ADHB) East Lombok District year 2016-2019 shows a change in numbers that are quite significant or show a number that continues to increase. The highest increase occurred in 2018 while the lowest occurred in 2019. If viewed in total over the last four years pad increase figure of Rp 129,932,447.3 or if viewed on average then the increase of PAD to PDRB based on the price applies annually of Rp 32,483,111.80.

Furthermore, to see the level of sensitivity of Regional Native Income to Brutto Domestic Regional Product on the basis of constant price (ADHK), it will first be seen the change of each variable referred to through the presentation of table 12.

Table 12. Rate of Change of Regional Native Income (PAD) to Brutto Domestic Regional Product (PDRB) Based on Constant Price in 2010 (ADHK) East Lombok District year 2016-2019 (in

\begin{tabular}{llllll}
\multicolumn{5}{c}{ percent) } \\
\hline No. & Year & P A D & PDRB (ADHK) & $\Delta$ PAD & $\Delta$ PDRB \\
\hline 1. & 2016 & $194.391 .179,0$ & 10.721 .723 & $29.158 .676,3$ & $448.981,9$ \\
2. & 2017 & $228.695 .504,7$ & 11.249 .937 & $34.304 .325,7$ & $528.214,0$ \\
3. & 2018 & $269.053 .535,0$ & 11.913 .551 & $40.358 .030,3$ & $663.614,0$ \\
4. & 2019 & $295.164 .950,0$ & 12.535 .284 & $26.111 .415,0$ & $621.733,0$ \\
& Amount & $987.305 .168,7$ & 46.420 .495 & $129.932 .447,3$ & $2.262 .542,9$ \\
& Average & $246.826 .292,2$ & 11.605 .123 & $32.483 .111,8$ & $565.635,7$ \\
\hline
\end{tabular}


Based on the table data above can be explained that the Rate of Change in Regional Native Income (PAD) to Product Domestic Regional Brutto (PDRB) On the Basis of Constant Prices in 2010 (ADHK) East Lombok District year 2016-2019 shows a change in numbers that are quite significant or show a number that continues to increase. The highest increase occurred in 2018 while the lowest occurred in 2019. If viewed in total over the last four years the number of pad increase to PDRB amounted to $\mathrm{Rp} 2,262,542.9$ or if viewed on average then the increase of PAD to PDRB based on the prevailing price annually amounted to $\mathrm{Rp} 565,635.7$.

Furthermore, to see the amount of elasticity of PAD to PDRB reviewed on the Basis of Applicable Price (ADHB), then the data feed will be seen in table 10.

Table 10. The elasticity of Regional Original Income (PAD) to Brutto Domestic Regional Product (PDRB) Based on Applicable Price (ADHB) in East Lombok District year 2016-2019 (in percent)

\begin{tabular}{cllcc}
\hline No. & Year & $\Delta$ P A D & $\Delta$ PDRB (ADHB) & ELASTISTAS $(\%)$ \\
\hline 1. & 2016 & $29.158 .676,3$ & $1.341 .642,9$ & 4,59 \\
2. & 2017 & $34.304 .325,7$ & $1.578 .403,5$ & 4,60 \\
3. & 2018 & $40.358 .030,3$ & $1.279 .011,5$ & 3,17 \\
4. & 2019 & $26.111 .415,0$ & $1.477 .137,6$ & 5,66 \\
& Amount & $129.932 .447,3$ & $5.676 .177,5$ & 18,02 \\
& Average & $32.483 .111,8$ & $1.419 .044,4$ & 4,50 \\
\hline
\end{tabular}

Based on the data table above can be explained that the level of sensitivity or elasticity of PAD to PDRB in East Lombok Regency since 2016-2019 is shown in the table above. Quantitatively the amount of elasticity every year centering undergoes changes. For example, the amount of elasticity of PAD to PDRBi based on the prevailing price in 2016 is $4.59 \%$, in 2017 it is $4.60 \%$, in 2018 it is $3.17 \%$ and in 2019 it is $5.66 \%$. if viewed on average for 4 (four) years, then the amount of elasticity of PAD to PDRB annually is $4.50 \%$. This means that if the regional revenue increases by one percent, it will have implications for the increase in PDRB by 4.5 percent from the previous year.

Furthermore, to see the amount of elasticity of PAD to PDRB reviewed on the basis of Constant Price in 2010, then the data serving will be seen in table 11.

Table 11. The elasticity of Regional Native Income (PAD) to Brutto Domestic Regional Product (PDRB) Based on Constant Price in 2010 in East Lombok District in 2016-2019 (in percent)

\begin{tabular}{cllcc}
\hline No. & Year & $\Delta$ P A D & $\Delta$ PDRB $($ ADHK) & ELASTISTAS \\
\hline 1. & 2016 & $29.158 .676,3$ & $448.981,9$ & 1,54 \\
2. & 2017 & $34.304 .325,7$ & $528.214,0$ & 1,53 \\
3. & 2018 & $40.358 .030,3$ & $663.614,0$ & 1,64 \\
4. & 2019 & $26.111 .415,0$ & $621.733,0$ & 2,38 \\
& Amount & $129.932 .447,3$ & $2.262 .542,9$ & 7,09 \\
& Average & $32.483 .111,8$ & $565.635,7$ & 1,78 \\
\hline
\end{tabular}

Based on the data table above can be explained that the level of sensitivity or elasticity of PAD to PDRB in East Lombok Regency since 2016-2019 quantitatively the amount of elasticity every year changes. For example, the elasticity of PAD to PDRB based on the prevailing price in 2016 was $1.54 \%$, in 2017 it was $1.53 \%$, in 2018 it was $1.64 \%$ and in 2019 it was $2.38 \%$. if viewed on average for 4 (four) years, then the amount of elasticity of PAD to PDRB annually is $1.78 \%$. This means that if the regional revenue increases by one percent, it will have implications for the increase in PDRB by $1.78 \%$ from the previous year. 


\section{Conclusion}

The rate of development of Regional Native Income (PAD) to Brutto Domestic Regional Product (PDRB) on the Basis of Prevailing Prices (ADHB) east Lombok Regency in 2016-2019 as follows shows that in 2016 the growth was 9.75 percent, in 2017 increased slightly to 10.62 percent, in 2018 it fell to 10.33 percent, in 2019 to 10.47 percent. The highest growth rate occurred in 2017 which was 10.62 percent. The average growth rate for 4 (four) years starting from 2016-2019 reached 10.29 percent. The rate of development of Regional Native Income (PAD) to Brutto Domestic Regional Product (PDRB) on the Basis of Constant Prices in 2010 in East Lombok District in 2016-2019 showed that in 2016 the contribution growth was 10.04 percent, in 2017 increased to 10.53 percent, in 2018 increased to 11.06 percent, in 2019 increased again to 11.21 percent. The highest growth rate occurred in 2019 which was 13.95 percent. The average growth rate for 4 (four) years starting from 2016-2019 reached 11.36 percent. The contribution of balance funds to the revenues of East Lombok Regency is very influential so that the impact on the rate of economic growth is reflected in the growth of PDRB (ADHB) and ADHK east Lombok regency during 4 (four) years (2016-2019) is relatively significant. Pad elasticity to PDRB both On The Basis of Prevailing Prices and On a Constant Price Basis in 2010 on average for the last 4 (four) years shows a trend that is positional or Elastic. This means that if PAD increases by one unit (\%), then PDRB will increase by more than one unit $(\%)$.

\section{References}

Arifin, K. Z. (2020). Elastisitas Produk Domestik Regional Bruto Terhadap. Eksistansi, 9(2), 1315-1325.

Dama, H. Y., Lapian, A. L. C., Sumual, J. I., Pembangunan, J. E., Ekonomi, F., Sam, U., \& Manado, R. (2016). Pengaruh Produk Domestik Regional Bruto (Pdrb) Terhadap Tingkat Kemiskinan Di Kota Manado (Tahun 2005-2014). Jurnal Berkala Ilmiah Efisiensi, 16(3), 549-561.

Juniarsih, T., Safrida, \& Makmur, T. (2021). Pengaruh Produk Domestik Regional Bruto ( Pdrb ) Sektor Pertanian Di Aceh Terhadap Produk Domestik Regional Bruto ( PDRB ) Provinsi Aceh. Jurnal Ilmiah Akuntasi Keuangan Dan Bisnis, 2(1).

Kuncoro, M. (2003). Metode Riset Untuk Bisnis dan Ekonomi (Bagaimana meneliti \& menulis tesis. Penerbit Erlangga, Jakarta

Oktaviana, N., \& Amalia, N. (2018). Gross Regional Domestic Product Forecasts Using Trend Analysis: Case Study of Bangka Belitung Province. Jurnal Ekonomi \& Studi Pembangunan, 19(2). https://doi.org/10.18196/jesp.19.2.5005

\section{Copyrights}

Copyright for this article is retained by the author(s), with first publication rights granted to the journal.

This is an open-access article distributed under the terms and conditions of the Creative Commons Attribution license (http://creativecommons.org/licenses/by/4.0/). 